\title{
Sübsidans Nedeniyle Elek Yolu ve Açık Ocak Şevlerinde Meydana Gelen Deformasyonların Değerlendirilmesi: Soma-Kısrakdere Kömür Sahası için Örnek Bir Çalışma
}

Evaluation of the Deformations Occured in the Run-Off Mine Road and Open-Pit Slopes Due to the Subsidence: A Case Study for Soma-Kisrakdere Coal-Field

\section{Cem KINCAL ${ }^{1}$, Doğan KARAKUŞ ${ }^{2}$, Ahmet Hakan ONUR ${ }^{2}$, Mehmet Yalçın KOCA ${ }^{1}$}

${ }^{1}$ Dokuz Eylül Üniversitesi, Mühendislik Fakültesi, Jeoloji Mühendisliği Bölümü, İMIR

${ }^{2}$ Dokuz Eylül Üniversitesi, Mühendislik Fakültesi, Maden Mühendisliği Bölümü, IZMIR

$\begin{array}{lll}\text { Geliş (received) } & : & \text { 03 Kasım (November) } 2014 \\ \text { Düzeltme (revised) } & : & 10 \text { Aralık (December) } 2014 \\ \text { Kabul (accepted) } & : & 12 \text { Aralık (December) } 2014\end{array}$

ÖZ

$\mathrm{KM}_{2}$ ve $\mathrm{KM}_{3}$-linyit damarları, Miyosen yaşlı Soma formasyonu'nda yer alan Kısrakdere kömür zonunda oluşmuştur. Soma-Eynez kömür sahasındaki Neojen yaşlı istifin tabanında yer alan çamurtaşlarını üzerleyen sınırın hemen üzerindeki $\mathrm{KM}_{2}$-kömür damarının kalınlığı 1 ile 25 m arasında değişmektedir. Saha, Türkiye'deki belli başlı büyük kömür üretim alanlarından birisidir. Yeraltı kömür üretimi Miyosen yaşlı $\mathrm{M}_{2}$ marnlarının üzerinde yer alan $\mathrm{KM}_{2}$-kömür damarında yürütülmektedir. Işılar uzunayak panellerinde yeraltı kömür üretimi nedeniyle oluşturulmuş olan yeraltı açıklıkları yüzeyden $291 \mathrm{~m}$ derinliktedir. Kireçtaşı $\left(\mathrm{M}_{3}\right)$ ve marn $\left(\mathrm{M}_{2}\right)$ katmanları, tasman nedeniyle deforme olmuş ve çatlaklı bir yapı kazanmıştır. Böylelikle, oluşan boşlukların birbirleriyle bağlanması ve açıklıklara doğru ilerlemesi, elek yolunun çökmesine neden olmuştur. Tasmandan etkilenen yüzey alanının sınırı etki açısıyla tanımlanır. Tasman, yeraltı açıklıklarının merkezine yakın değil, uzun ayak panellerini düşey olarak kesen fay zonu üzerinde büyük miktarda farklı oturmalara neden olmuştur. Sonuç olarak, sahada asimetrik bir sübsidans profili meydana gelmiştir. Yüzeydeki çatlakların boyutu ve yayılımının, sahadaki tasman hareketi tamamlanıncaya kadar artarak devam etmesi beklenmektedir. Elek yolu üzerindeki çatlak desenlerinin gelişiminin, tasman profili boyunca farklılıklar sunduğu belirlenmiştir. Farklı çatlak desenleri, bu profilin çekme ve çökme bölgelerinde gözlenmiştir. Sübsidanslar elek yoluna paralel ve dik alınmış kesitlerde incelenmiştir. Bu nedenle kesitler üzerinde farklı kırılma açıları bulunmuştur. Bunun birinci nedeni; kesitlerin kömür damarına ve faya dik veya paralel konumda olması, ikincisi ise; her iki kesitin birbirlerinden farklı topoğrafyalara sahip olmasıdır. Çünkü Kuzey - Güney yönünde alınmış kesit şevli bir topoğrafyaya sahiptir. Bu çalışmada, çatlak desenleri tasman profilinin oluşturulmasında kullanılmıştır. Kömür üretim panellerinin tesir açısı iki farklı kesitte incelenmiştir. K-G yönünde alınmış kesitte uzun ayak panolarının

C.Kıncal

E-posta : cem.kincal@deu.edu.tr 
Kıncal, Karakuş, Onur, Koca

her iki tarafi için sınır açıları sonlu elemanlar yöntemiyle belirlenmiştir. Doğu - Batı yönünde alınmış kesitte yer yüzeyinde gelişmiş farklı tasman çatlak desenleri ve elek yolu boyunca tesis edilmiş noktalardaki deformasyon ölçümleri yardımıyla sınır açıları belirlenmiştir. Her iki yöntemden elde edilen sonuçlar birbiriyle deneştirilmiştir. İki yöntemden elde edilen açısal farkların $7^{\circ}$ ile $10^{\circ}$ arasında değiştiği belirlenmiştir.

Anahtar Kelimeler: Kömür, Deformasyon, Kısrakdere (Soma), Sübsidans.

\section{ABSTRACT}

$\mathrm{KM}_{2}$ and $\mathrm{KM}_{3}$-lignite seams occur in the Kisrakdere coal zone of Miocene aged Soma formation. The thickness of the $\mathrm{KM}_{2}$ coal seam varies between 1 and 25 meters above the contact with the underlying mudstones at the base of the Neogene sequence in the Soma-Eynez coal field. This field is one of the major coal production areas in Turkey. Underground coal production has been conducted in the $\mathrm{KM}_{2}$-coal seam located above the $M_{2}$-marl unit with Miocene in age. Subsurface openings in Issiklar longwall-panels is located at $291 \mathrm{~m}$ depth from the ground-surface level created due to the underground coal mining. Limestone $\left(M_{3}\right)$ and marl $\left(M_{2}\right)$ layers deformed and formed a jointed structure due to the subsidence. Thus, these voids fractured and collapsed into the openings, with resultant lowering of the ground surface on the run-off mine road. The boundary of the surface area affected from the subsidence is defined by the angle of influence. Subsidence caused differential settlement, with the greatest amount on a fault zone which vertically cuts the longwall panels, not near the center of the opening. As a result, asymmetrical subsidence profile developed in the area. The extend and size of ground surface cracks are expected to increase until the subsidence is completed in the area. The development of ground-crack patterns on the run-away mine showed some differences along the subsidence profile. Different crack patterns were observed in the extraction and the gap zones (subsided zone) of this profile. These patterns were used in the constitution of subsidence profile in this work. Subsidence was investigated in the cross-sections constructed by either vertical or parallel to the run-off mine road. Different break angles were determined on these sections. The causes obtained different break angles are due to the preparation of the cross-sections both parallel and vertical to the fault zone and the coal seam, and different topography. Because the cross-section constructed in $\mathrm{N}-\mathrm{S}$ direction has a topography with slope. The angle of influence (limit angle) about the coal production panels were investigated in two different cross-sections. In the cross-section with N-S direction, limit angles for both sides of the longwall panel were determined by using the finite element method. In the crosssection with E-W direction, limit angles were determined on the cross-section produced with the help of the different subsidence crack patterns developed on the ground surface and the measurements of deformation on the survey points along the run-off mine road. The results obtained from the two methods were correlated with each other. It was determined that angular differences acquired from the two methods have a range changing between $7^{\circ}$ and $10^{\circ}$.

Key Words: Coal, Deformation, Kisrakdere (Soma), Subsidence. 


\section{GİİŞ}

Soma TKİ (Türkiye Kömür İşletmeleri) sahası, Kısrakdere bölgesi, Işıklar yeraltı ocağında kömür üretiminin neden olduğu çökme (sübsidans) etkisiyle elek yolunda ve yeraltı üretim panolarının üst kısmında yer alan açık ocak şevlerinde deformasyonlar meydana gelmiştir. Yeraltı kömür madenciliği nedeniyle meydana gelen yeraltı boşlukları yüzeyde yer alan elek yolu üzerinde tasman çatlaklarının gelişmesine neden olmuş ve yol işlevini kaybetmiştir (Şekil 1). $\mathrm{Bu}$ çatlakların yüzeyde meydana getirdiği kırık desenlerini (çatlak paternlerini), yeraltı boşluğunun geometrisine ve damar eğimine bağlı olarak gelişen çökme profilindeki çekme ve çökme bölgelerindeki gerilmeler tayin etmektedir (Whittaker ve Reddish, 1989; Singh ve Dhar, 1997; Oncioiu ve Onica, 1999; Onargan vd., 2000; Aksoy vd., 2004). Ayağın uzun eksenine dik bir kesitte, çökme bölgesinde baskın olarak yer altı üretim panosunun (uzun ayağın) hem uzun hem de kısa eksenine, çekme bölgesinde de sadece kısa eksenine dik yönde yüzey kırıkları oluşmaktadır (Şekil 1a ve 1b). Çekme ve çökme bölgelerinin sınırlarında ise

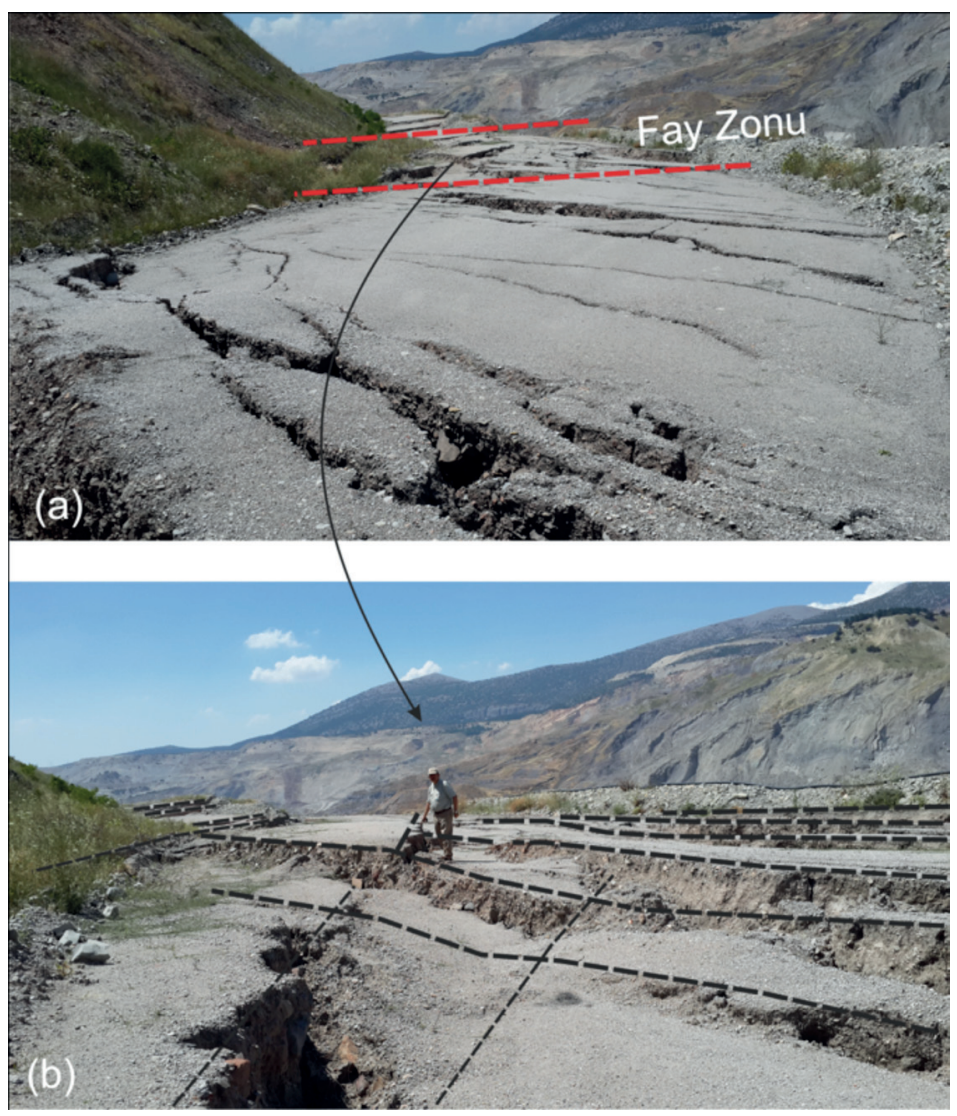

Şekil 1. (a) Elek yolunda gözlenen tasmanlar ve ana fay zonunun (K28D/90) konumu.

(b) Fayın etki bölgesinde fayın doğrultusuna dik ve paralel doğrultuda gelişmiş tasman çatlakları.

Figure 1. (a) Displacements observed along the run-off mine road and main position (K28D/90) of the fault zone, (b) Subsidence cracks developed parallel and vertical to the strike of the fault in its zone of influence. 
ayağın uzun ekseniyle dar açı yapacak şekilde gelişmiş verevine çatlaklara rastlanmaktadır. Ayaklar fay gibi tektonik bir hattı kesiyorsa, yüzeyde tasman çatlak desenleri ve sübsidans profili de değişmektedir. Bu kapsamda, elek yolu boyunca 10 farklı noktada, tasman ölçümleri periyodik olarak alınmış ve ölçümlerin sonuçları uzun ayakları dikine kesen fayın etki bölgesiyle ilişkilendirilmiştir. Ölçüm noktalarının faya olan mesafeleriyle bu noktalardaki toplam tasman miktarlarının değişimi incelenmiştir. $\mathrm{Bu}$ ilişkilendirmeden amaç; yaklaşık $25^{\circ}$ eğimli kömür damarı ve düşey fay zonunun varlığ1 nedeniyle çökme profilinde yer alan çökme ve çekme bölgelerinin lokasyonlarının (National Coal Board, 1975) nasıl değiştiğini yüzeyde gelişen çatlak desenlerini ve ölçüm noktalarındaki yer değiştirme miktarlarını dikkate alarak (kazık ölçümleri) kestirmektir. Kömür üretimi yapılan ve $291 \mathrm{~m}$ derinlikte yer alan uzun ayaklar başlangıç noktasından itibaren birinci ayakta 105 $\mathrm{m}$, ikinci ayakta $165 \mathrm{~m}$ mesafelerinde, konumu K28D/90 olan düşey bir fay tarafından kesilmiştir (Şekil 1a). Bu çalışmada, yüzeydeki tasman çatlak desenlerinin bu faydan nasıl etkilendiği incelenmiş ve oluşacak sınır açıları ayaklar hazırlanmadan önce tahmin edilmiştir. Sınır açıları iki farklı kesitte incelenmiştir: birincisi; $\mathrm{K}-\mathrm{G}$ yönünde alınmış ve şevli topoğrafyaya sahip kesit üzerinde Phase ${ }^{2}$ v.7 (2014) bilgisayar programı yardımıyla, ikincisi ise; D-B yönlü elek yoluna koşut alınmış kesit üzerinde, yüzeyde gelişen çatlak desenleri ve kazık ölçümleri yardımıyla elde edilen sübsidans profilinden, doğrudan açı ölçülerek gerçekleştirilmiştir. İki kesit arasındaki temel farklar; K-G yönlü

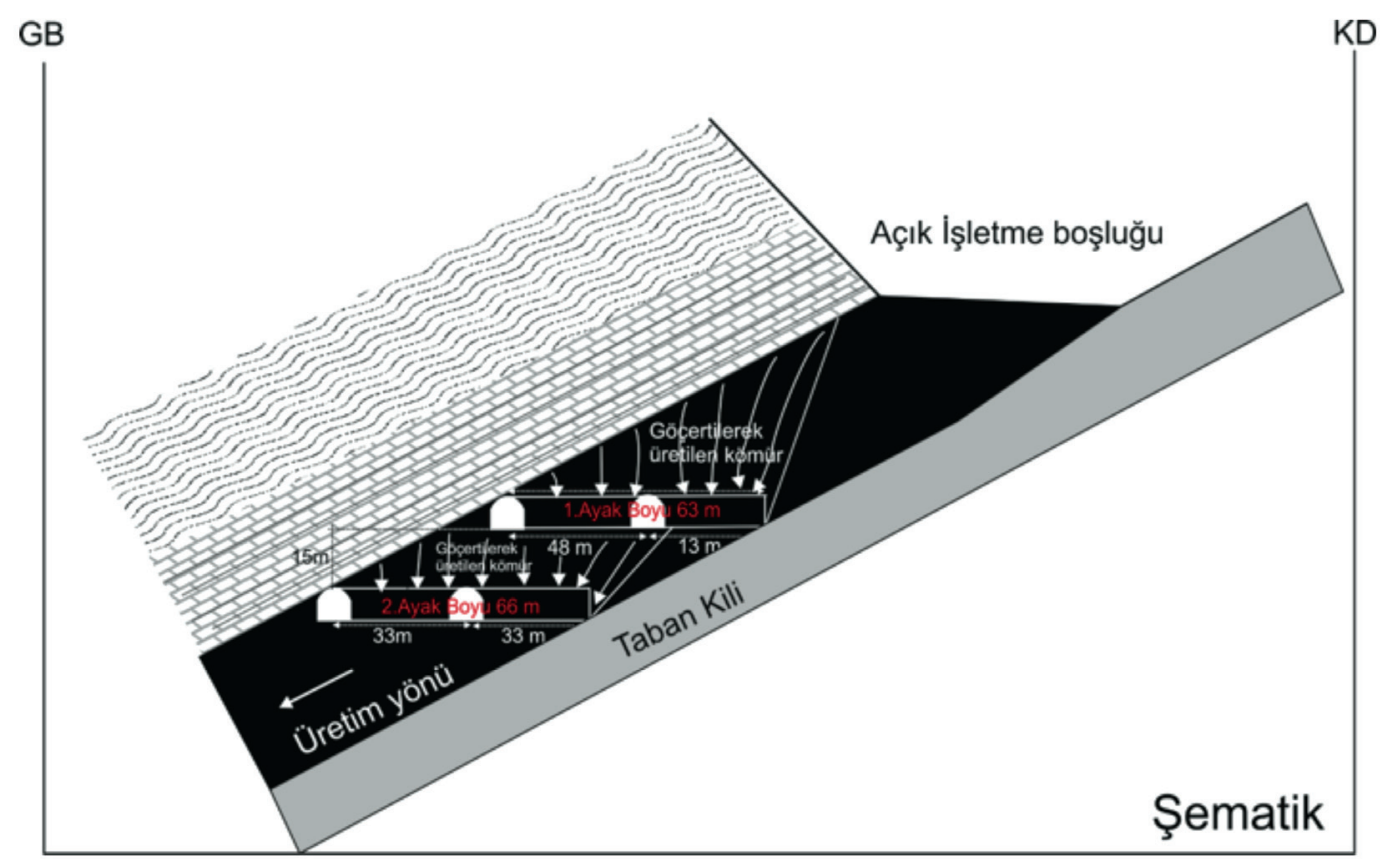

Şekil 2. Uzun ayakların kömür eğimiyle ilişkisi.

Figure 2. Locational relationship between the dip angle of the coal bed and the long walls. 
kesitin fayı kesmemesi (faya paralel kesit), şevli topografyaya sahip olması, D-B yönlü kesitin ise; düz topografyaya (yola paralel kesit) sahip olmas1, kömürün doğrultusuna paralel kesitte incelemenin yapılması ve kesitin fayı kesmesidir. Makalede bu farklılıkların kırılma açılarında meydana getireceği değişim araştırılmıştır.

Yeraltı ocağında göçertmeli geri dönümlü uzun ayak yöntemi ile kömür üretimi gerçekleştirilmektedir. Havzada yürütülen kalın kömür damarı üretim ilkesi bu ocakta da uygulanmaktadır. Buna göre yaklaşık $25^{\circ}$ eğimli ve kalınlığı 14 ile $23 \mathrm{~m}$ arasında değişen kömür damarı doğrultu boyunca oluşturulan uzun ayak panolarıyla yukarıdan aşağıya doğru arkadan göçertmeli mekanize ayak teçhizatı kullanılarak üretilmektedir. Kısa dönem yeraltı üretim planı olarak öncelikle 4 adet panonun planı yapılmıştır. İki adet mekanize teçhizat ile eş güdümlü yürütülen üretim çalışmaları Aralık 2013 tarihinde hazırlık galerilerinin tamamlanmasından sonra başlamıştır.

İncelenen bölgedeki şev geometrisi açı ocak çalışmalarına bağlı olarak Kasım 2008 tarihinde oluşmuştur. Kasım 2008 tarihinden Aralık 2013 tarihine kadar bölgede bir kazı çalışması gerçekleştirilmemiştir. Yeraltı üretim çalışmalarının Aralık 2013 tarihinde başlamasından kısa bir süre sonra tasman çatlakları elek yolu üzerinde izlenmeye başlamıştır ve yeraltı üretim çalışmaları ilerledikçe gelişim göstermiştir. Çatlakların ilk gözlenmeye başlanmasından itibaren bölgede konumlandırılan 10 adet kazığın konum ölçümlerine başlanmıştır. Yeraltı üretim çalışmalarının zaman içinde çeşitli nedenlerle durmasına bağlı olarak kazıkların da hareketleri yavaşlamış, üretim çalışmalarının tekrar başlamasıyla kazık hareketlerinde hızlanma gözlenmiştir. Yeraltı üretim çalışmalarında 1-nolu ayak boyu $63 \mathrm{~m}$, pano uzunluğu 422 metredir (Şekil 2). 2-nolu ayak boyu $66 \mathrm{~m}$ ve pano uzunluğu 456 metredir. İki ayak arasındaki düşey mesafe 15 metredir. Panoların eğimleri $3.6^{\circ}-4.7^{\circ} \mathrm{GD}^{\prime}$ dur. Yeraltı uzun ayakları (üretim panoları) dört adet olarak planlanmış ancak ikinci ayak tamamlandıktan sonra elek yolunda gelişen tasmanlar nedeniyle üretime ara verilmiştir.

Kömür üretim panoları (ayaklar), elek yolu ve bu yolu dikine kesen ve tasman çatlağ oluşum şekillerini denetleyen ana fay zonunun konumları ve bunların birbirleriyle olan ilişkileri Şekil 3a ve 3b'de verilmiştir. Elek yolu üzerinde gelişen deformasyonlar, yolun $291 \mathrm{~m}$ altında $165 \mathrm{~m}$ kotunda gerçekleştirilen kömür üretimi nedeniyle meydana gelmiştir.

Elek yolu boyunca çökme etki mesafesinin uzunluğu $(\mathrm{L})=\mathrm{W}+1.4 * \mathrm{~h}=422+1.4 *(456-$ $165)=829.4 \mathrm{~m}$, ikinci ayak için; $\mathrm{L}=450+1.4 *$ $(456-150.5)=877.7$ metredir. Burada, W: Ayak uzunluğu (m), h: Ayak derinliğidir (m). Kömürün $25^{\circ}$ güneydoğuya eğimli olması ve kömür damarının düşey bir fay (K28D/90) tarafindan kesilmesi topoğrafik yüzeylerden birisinin açık ocak şevi olması nedeniyle incelenen sahada asimetrik bir çökme profilinin gelişmesine neden olmuştur (Şekil 4).

\section{YÖNTEM}

$\mathrm{Bu}$ çalışmada, öncelikle çökme nedeniyle meydana gelen çatlakların konumları belirlenerek haritalanmıştır. Daha sonra, tasman çatlak ölçülerinin kontur diyagramı çıkartılarak bu diyagram üzerinde çatlak paternlerinin (desenlerinin) ve elek yolunu dikine kesen ana fay zonunun konumsal ilişkileri stereografik projeksiyon teknikleri kullanılarak analiz 


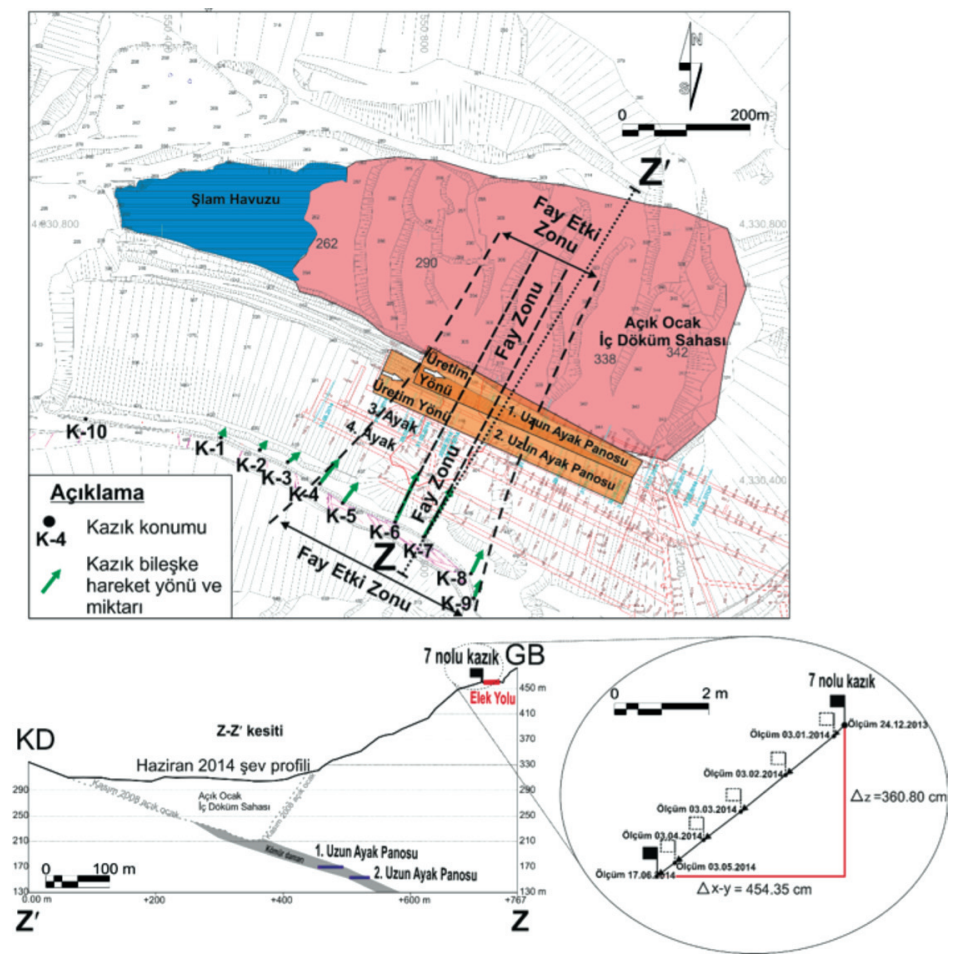

Şekil 3a. Tasman hareket yönleri, yer altı kömür üretim panoları, ana fay zonu ve elek yolunun konumsal ilişkileri.

Figure 3a. Locational relations among movement directions of the subsidences and underground coal production panels and run-off mine road.

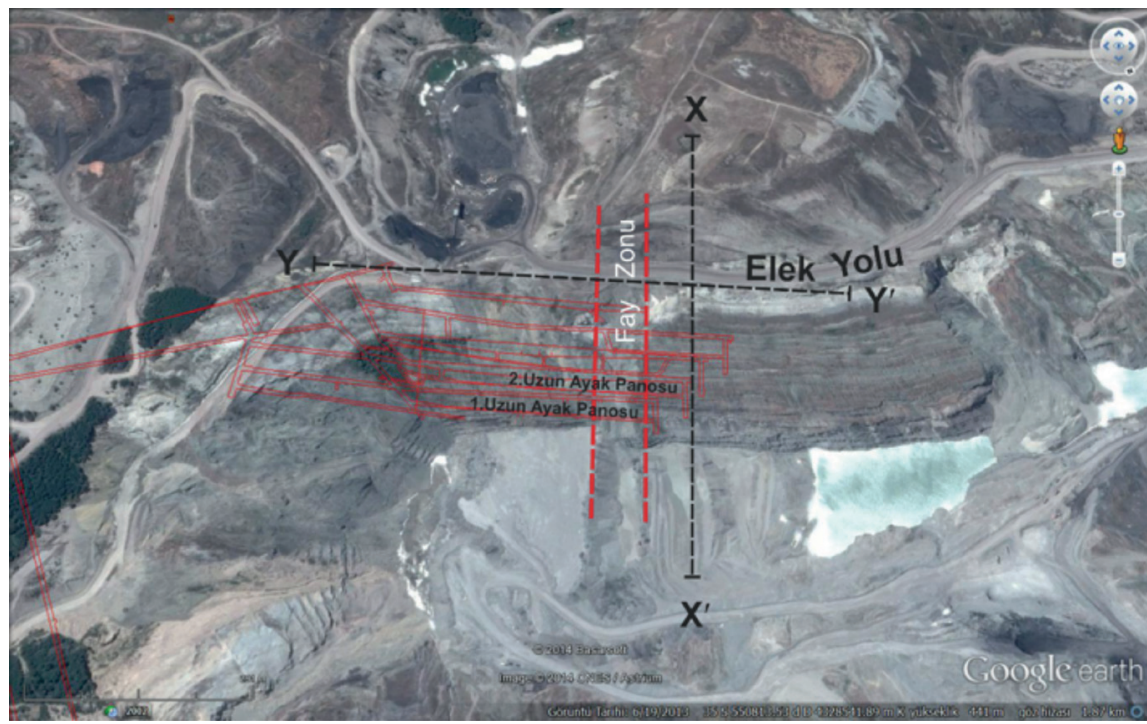

Şekil 3b. Ana fay zonu, elek yolu ve eski harman sahasının konumsal ilişkileri (X-X': Kömür damarını dikine kesen kesitin iziPhase $e^{2}$ yazılımıyla analizi yapılmıştır, Y-Y': Elek yoluna paralel alınan kesitin izi).

Figure 3b. Locational relations of the main fault zone and run-off mine road and old waste-tip field (X-X': Cross-section vertical to coal seam-analysed using Phase ${ }^{2}$ software, $\mathrm{Y}-\mathrm{Y}^{\prime}$ : Cross-section paralel to the run-off mine road). 


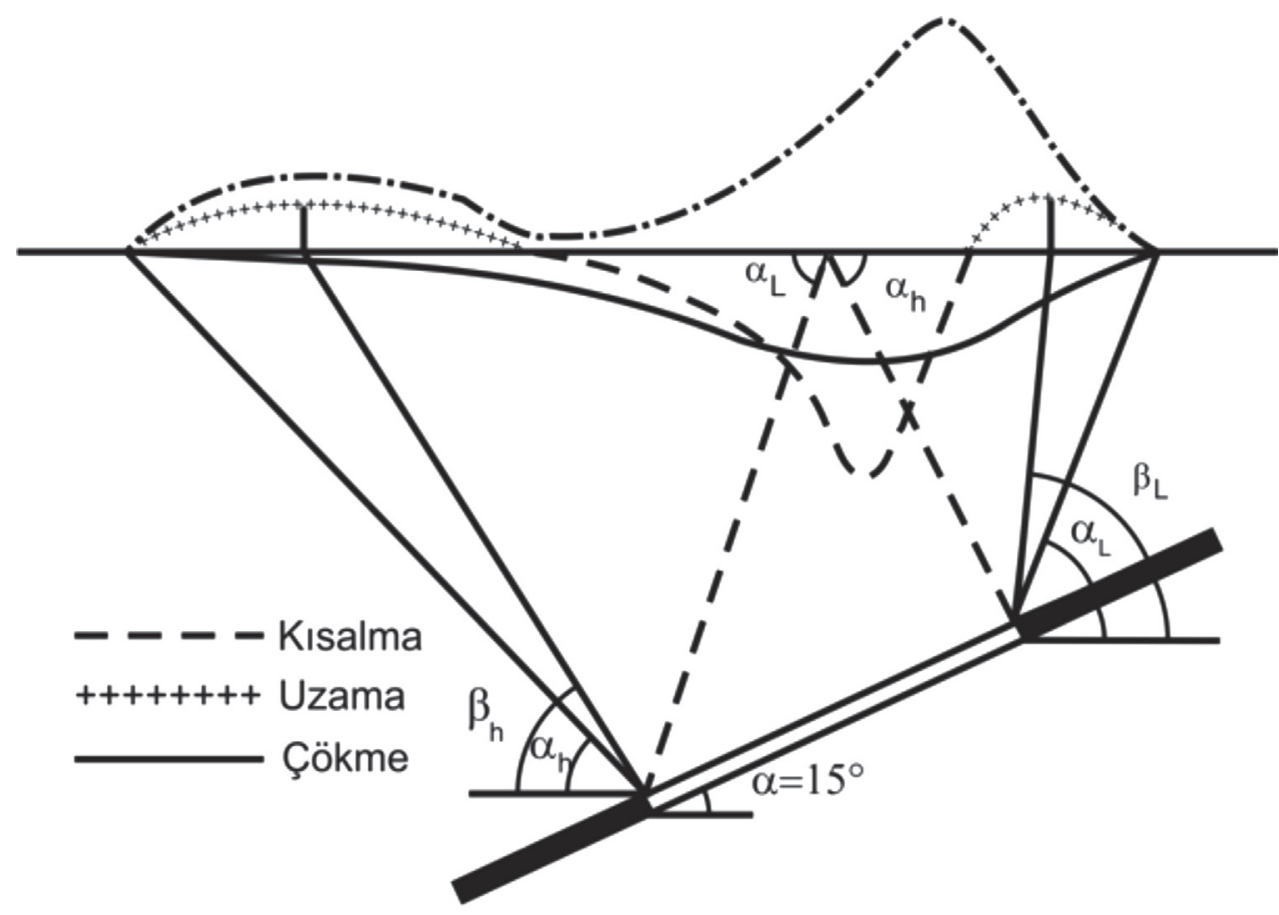

Şekil 4. Etki açısı ve mesafesini gösteren şematik şekil (faya paralel kesit).

Figure 4. Schematic figure showing limit angle and its distance (cross-section constructed parallel to the fault plane).

edilmiştir (Goodman, 1976; Koca ve Kıncal, 2004; Kincal ve Koca, 2009). Kinematik analizlerde Schmidt neti ve alt yarımküre projeksiyonu kullanılmıştır.

Tasman ölçüm noktalarında (10 nokta) yatay ve düşey yer değiştirmeler okunmuş ve sonuçlar bileşke yer değiştirme değeri olarak verilmiştir. Deformasyonların miktarının ve yönünün belirlenmesi için şev hareketinin üst kotlarında elek yolu üzerinde konumlandırılmış noktalarda tekrarlı konum ölçümleri yapılmıştır. Noktalar kazıklar çakılarak işaretlenmiş ve kazıkların tekrarlı ölçümleri total station konum ölçüm cihazı ile gerçekleştirilmiştir. Hareketli olmayan bölgeye kurulan total station ölçüm cihazları milimetre mertebesinde hassasiyetle bir noktanın konumunu belirleyebilmektedir. Kazık ölçümleri sonucunda elde edilen koordinat bilgilerinin analizi sonucunda kazıkların yönleri ve hareket miktarları belirlenebilmektedir. Kazıkların konumlarının analizinde üç boyutlu madencilik yazılımları kullanılmış, hareket yönleri şev hareketini temsil eden kazıklardan deformasyon analizleri gerçekleştirilmiştir.

Yeraltı kömür üretimi nedeniyle oluşacak yüzeysel çökme ve kayma miktarlarının önceden tahmin edilmesi amaciyla sonlu elemanlar modeliyle çalışan Phase ${ }^{2}$ v.7 (2014) bilgisayar programı kullanılarak analizler yapılmıştır. $\mathrm{Bu}$ modelde tabaka eğimleri, taban kili (çamurtaşı), $\mathrm{KM}_{2}$-kömür damarı, üretim yapılan uzun ayaklar ve modeldeki tüm birimlerin malzeme özellikleri modele yüklenerek analizler gerçekleştirilmiştir. Üretimi tamamlanan iki adet pano koordinatlaryyla 
modele yerleştirilmiştir. Analizler sonucunda yatay yer değiştirme (kayma) ve düşey yer değiştirme (çökme) miktarları hesaplanmıştır. Yatay yer değiştirme miktarının belirlenmesi, kömür üretimi nedeniyle gelişen yer değiştirmelerin yüzeyde yer alan şevlerde bir kayma hareketinin gelişip/gelişmeyeceğini anlamaya, gelişmesi durumunda kayma yerinin önceden tahmin edilmesine olanak sağlayacaktır. Düşey yer değiştirmeler ise elek yolunun her iki tarafinda ( $\mathrm{K}$ ve G) meydana gelmesi olası kırılma açılarının önceden tahmin edilmesine olanak sağlayacaktır. Bilgisayar programı yardımıyla ayaklarda üretime başlamadan önce oluşacak tasmanlar, bu tasmanların miktarı ve tasmanlar nedeniyle $\mathrm{M}_{3}$-kireçtaşlarının gerilmeler etkisiyle kırılıp/ kırılmayacağı, kırılması durumunda yamaçlarda meydana gelecek şev kaymalarının olası yerlerinin önceden belirlenebilmesi mümkün olmaktadır.

\section{INNCELEME ALANININ JEOLOJISİ}

İnceleme alanı ve yakın yöresinde, tüm Soma havzasındaki istiflenmeye uygun bir stratigrafik dizilim görülür. Temel birimleriyle (Mesozoyik yaşı kristalize kireçtaşı ve grovaklar) bunların üzerine açısal uyumsuzlukla oturan ve kömür düzeyleri içeren $\left(\mathrm{KM}_{2}\right.$ ve $\mathrm{KM}_{3}$ kömür damarları) Neojen yaşlı tortul birimler yer alır (Şekil 5). Yeraltı kömür madenciliği yapılan kömür seviyesi $\mathrm{KM}_{2}$ damarıdır. Stratigrafik kesitte $\mathrm{M}_{2}$ sembolüyle kireçtaşı bantları içeren marnlar, $\mathrm{M}_{3}$ sembolüyle de kiltaşı-kumtaşı ara seviyeleri içeren, gastropoda fosilli kireçtaşları gösterilmiştir. $\mathrm{P}_{1}$ formasyonu; kiltaş1, serisit pullu ve gevşek çimentolu ince taneli kumtaşlarından oluşur. $\mathrm{P}_{1}$, inceleme alanında gözlenen en zayıf (en düşük direnç parametrelerine sahip) jeolojik birimdir (Şekil 6). Sahada $\mathrm{M}_{2}$ marnlarının ve $\mathrm{M}_{3}$ kireçtaşı katmanlarının eğim yönleri (195/34,

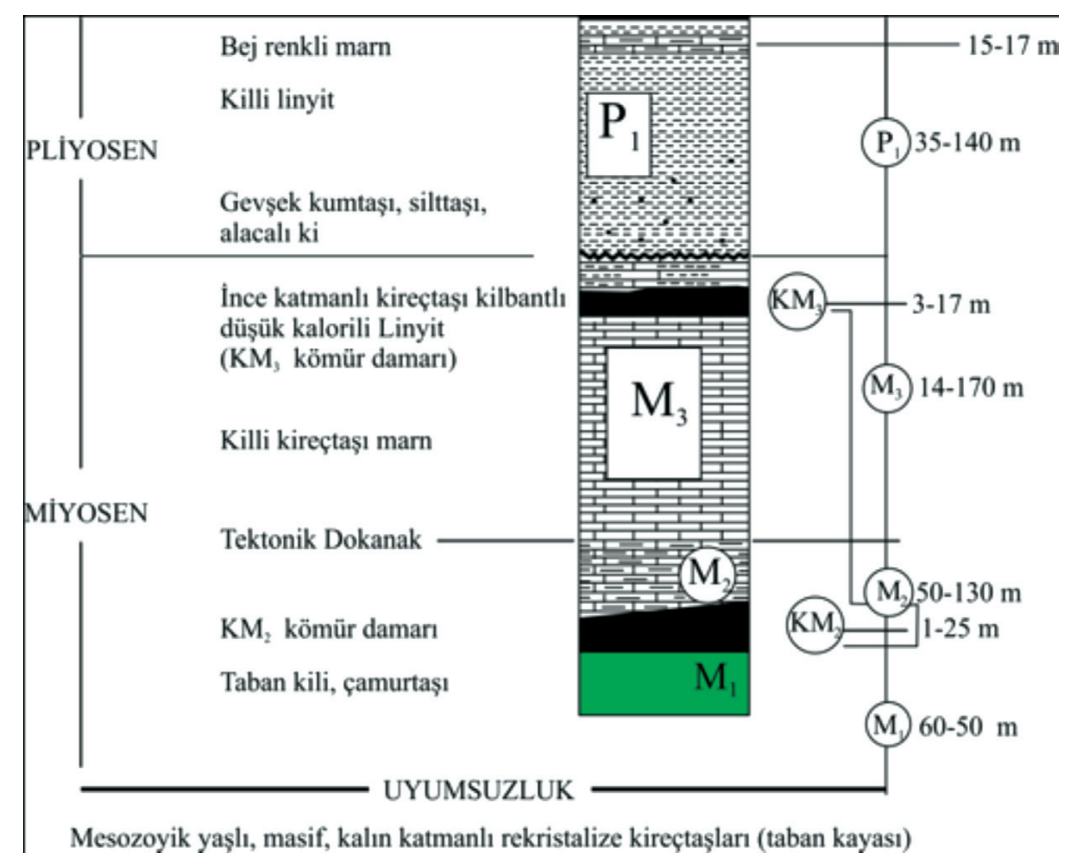

Şekil 5. İnceleme alanının stratigrafik kolon kesiti.

Figure 5. Stratigraphic columnar section of the study area. 


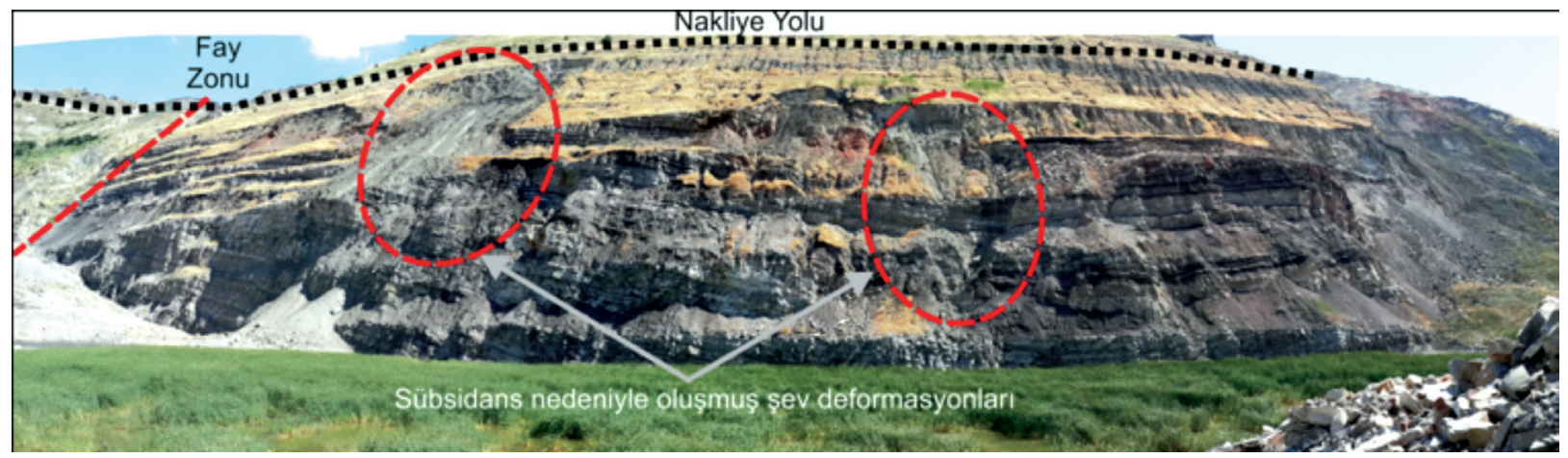

Şekil 6. $\quad \mathrm{M}_{3}$ biriminin üst seviyelerinde gözlenen $\mathrm{KM}_{3}$ kömür damarı ve $\mathrm{P}_{1}$-formasyonu arasındaki uyumlu dokanak ve elek yolunun kuzeyinde yer alan yüksek açılı yamaçlarda yer altı üretimi sonrasında meydana gelen şev deformasyonları.

Figure 6. $\mathrm{KM}_{3}$ coal seam observed in the upper levels of the $M_{3}$ unit and conformable contact with the $P_{1}$-formation and slope deformations observed after underground coal production in the steep slopes located in northern part of the run-off mine road.

190/33, 186/28) güneybatıya, bir diğer anlatımla yamaç içine doğrudur (Şekil 6). Katmanlanmaya dik gelişmiş çatlakların (115/90, 110/90, 108/90, 105/89) eğim yönleri ise şev tabanına doğrudur. Şekil 7'de katmanlar, çatlaklar, ana fay zonunun ve elek yolunun birbirleriyle olan konumsal ilişkileri gösterilmiştir.

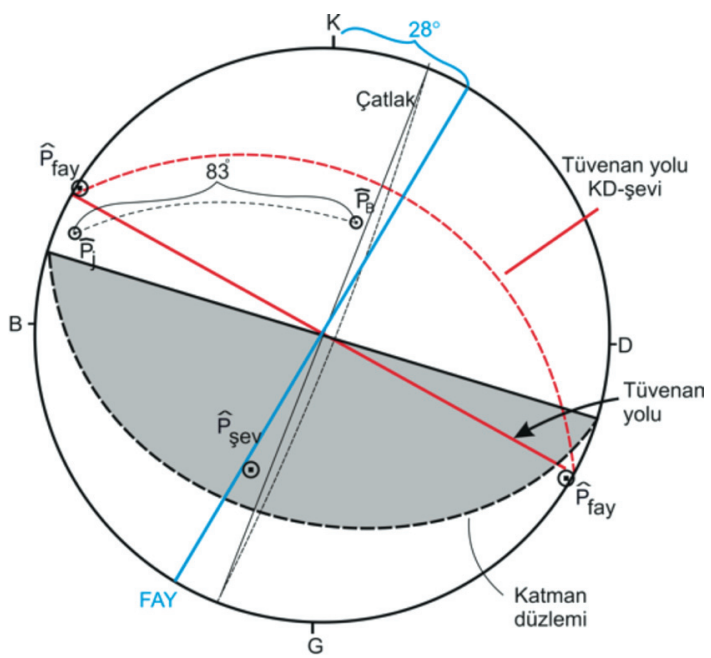

\section{SINIR AÇILARININ SONLU ELEMANLAR YÖNTEMIYLE BELİRLENMESI}

Oluşacak yüzeysel çökme ve kayma miktarlarının önceden tahmin edilmesi amacıyla, halen üretimi tamamlanmış olan ilk iki pano için sonlu elemanlar modeliyle $\mathrm{X}-\mathrm{X}^{\prime}$ kesiti üzerinde
Tüvenan yolunun kuzeydoğusunda yer alan şevin konumu : K63B/40-45KD Tabaka Konumu : 110/34

Çatlaklar : $110 / 85$

Ana Fay : $118 / 90$

Aynı tektonik aktivitenin sonucu olarak meydana gelmiş süreksizlikler

Şekil 7. Katmanlar, çatlaklar, fay zonu ve elek yolu arasındaki ilişkileri gösteren stereografik projeksiyon.

Figure 7. Stereographic projection showing the relationships among bedding planes, joints, fault zone and run-off mine road. 
analizler gerçekleştirilmiştir. $\mathrm{Bu}$ analizlerin gerçekleştirilebilmesi için Şekil 8'de verilen model K-G yönlü jeolojik kesitler (elek yoluna dik alınmış kesitler) kullanılarak hazırlanmıştır. $\mathrm{Bu}$ kesitler kömürün doğrultusuna dik alındığından gerçek eğimlerinde görülmektedir $\left(\mathrm{a}=25^{\circ}\right)$. Kömür damarının yüzeye çıktığı bölge daha önceden üretilmiş ve günümüzde dolgu yapılan Kısrakdere sahasının doğu kısmıdır.
Şekil 8'de oluşturulan model parametreleri analiz edilerek elde edilen yatay deplasmanlar (kayma) ve düşey deplasmanlar (çökme) sırası ile Şekil 9 ve 10 'da verilmektedir. Kaymanın hesaplandığı modelde, kayma hareketi hemen $\mathrm{KM}_{3}$-kömürünün üzerinde ve elek yolunda en yüksek değerlere ulaşmaktadır. Bu durum, arazi gözlemleriyle de desteklenmektedir. Şekil 10'da düşey yönde oluşan deplasmanların bittiği ve

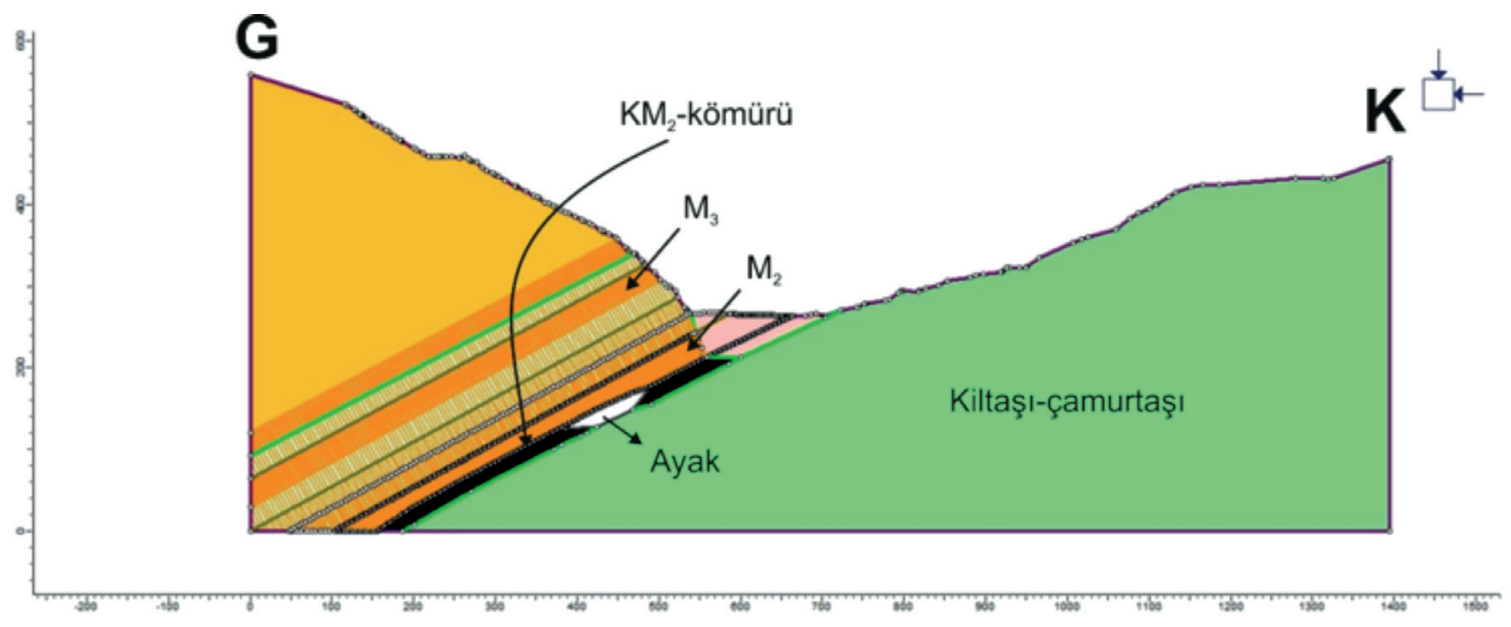

Şekil 8. Jeolojik kesit yardımıyla oluşturulan sonlu elemanlar modeli.

Figure 8. Finite element model of the geological cross-section.

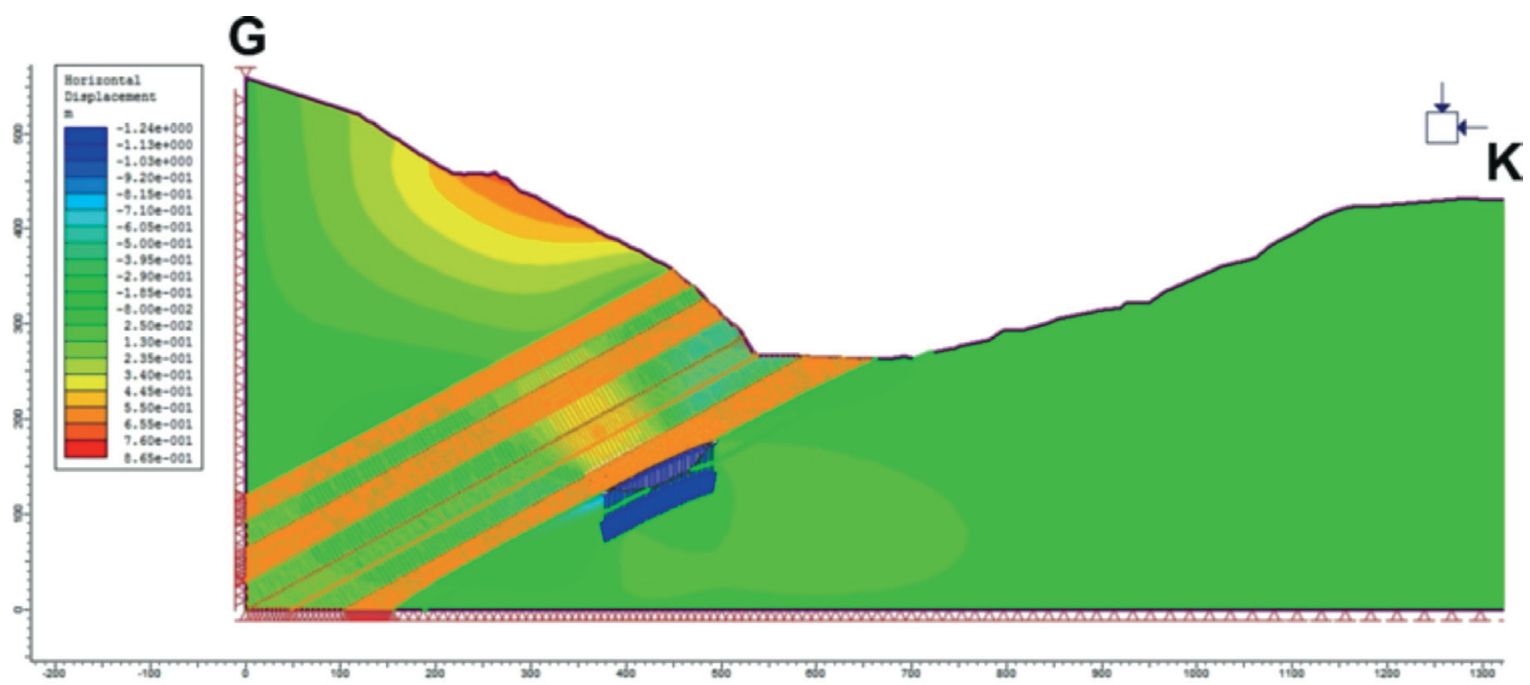

Şekil 9. Yeraltı kömür üretimi sonucunda oluşabilecek yatay deplasmanların sonlu elemanlar yöntemiyle belirlenmesi.

Figure 9. Determination of horizontal displacements after coal production by means of finite element model. 
hareketin sıfirlandığı bölgeler sınır alınmak üzere kömür damarında çizilen doğruların yatayla yaptığ 1 açılar sınır açısını oluşturmaktadır. Burada, daha az kot farkının oluştuğu iç döküm sahasının bulunduğu bölümde (elek yolunun kuzey tarafi) sınır açısı yaklaşık $38^{\circ}$, elek yoluna doğru daha fazla kot farkının oluştuğu bölümde ise (elek yolunun güney tarafi) $53^{\circ}$ olarak saptanmıştır (Şekil 10).

Sonlu elemanlar yöntemi kullanılarak elde edilen sonuçlar, iki ayağın üretiminin tamamlanması neticesinde çökmeye bağlı zemin hareketlerinin yüzeye ulaşacağını göstermiştir. Arazi gözlemleri sonucunda (13 Aralık 2013 ve 2 Ocak 2014 tarihlerinde), öngörülen hareketlerin başladığı, elek yolunda gerçekleştirilen ölçümler sonucunda saptanmış ve hareketin devam edeceği belirlenmiştir.

\section{ELEK YOLU ÜZERINDE GELIŞEN ÇATLAK DESENLERI}

Elek yolunun üzerinde gözlenen tasman çatlakları GPS yardımıyla haritalanmıştır (Şekil
11). Belirgin olarak izlenebilen, 31 adet tasman çatlağı harita üzerine aktarılmıştır. Tüm çatlaklar numaralandırılmış ve fotoğrafları çekilmiştir (Şekil 12 a ve b). 31 adet tasman çatlak ölçüsünden yararlanılarak kontur diyagramı hazırlanmış ve kutup yoğunlaşma noktaları elde edilmiştir (Şekil 12). Kutup yoğunlaşma noktalarını dikkate alan büyük daireler çizilmiştir.

I. Takım tasman çatlaklarının konumları $\mathrm{J}_{1}:$ 010/90 ve $\mathrm{J}_{2}:$ 040/90,

II. Takım tasman çatlaklarının konumu $\mathrm{J}_{3}$ : 085/90 olarak elde edilmiştir (Şekil 12).

III.Fay: 118/90 (K28D/90).

Çatlak takımlarını $\left(\mathrm{J}_{1}\right.$ ve $\mathrm{J}_{2}$ çatlak takımları) temsil eden düzlemlerin eğimleri $90^{\circ}$ olduğundan; stereogram üzerinde (Şekil 12) sadece doğrultularıyla temsil edilmiştir. Fay uzun ayakların tam ortasından değil, ayakların KB ucuna (başlangıç noktası) daha yakın olacak şekilde geçmektedir. Hem fayın bu konumu hem de kömür seviyesinin $25^{\circ}$ güneydoğuya eğimli olması sübsidans profilininin asimetrik şeklini

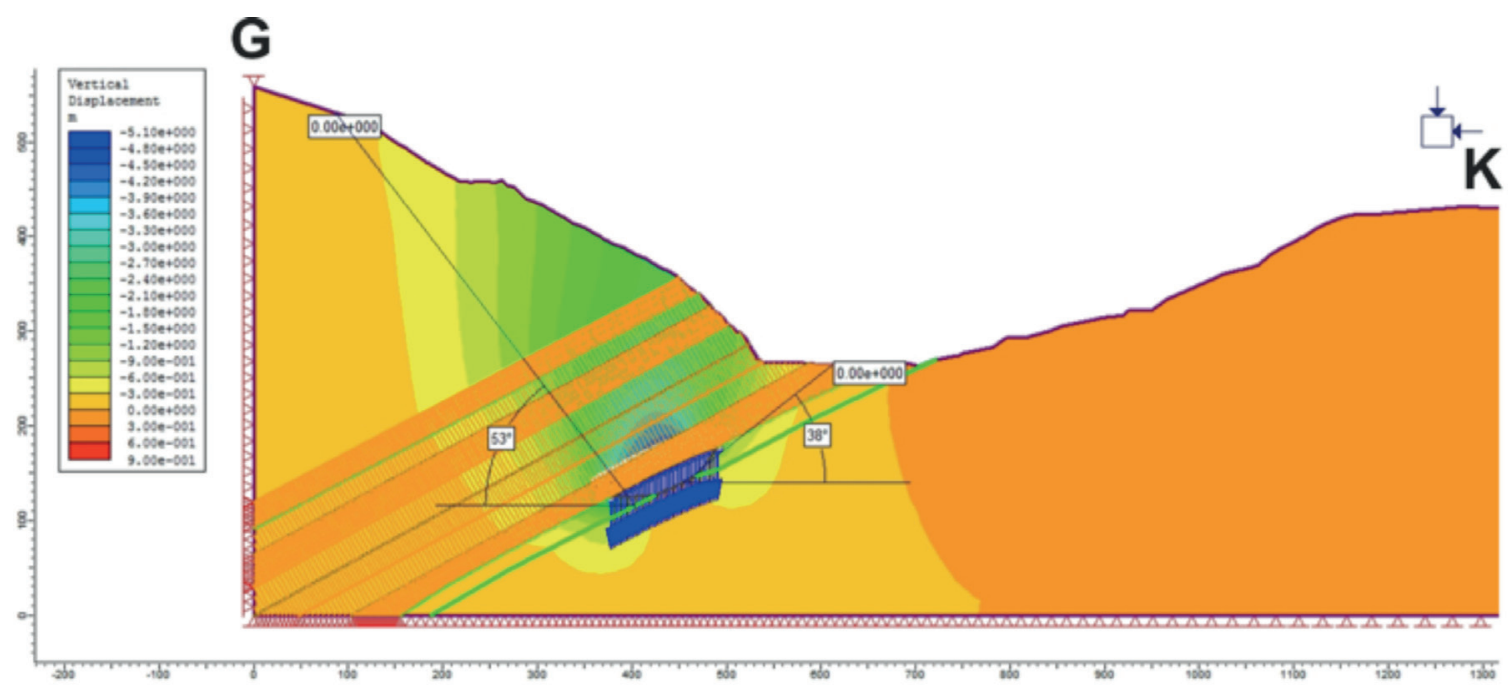

Şekil 10. Yeraltı kömür üretimi sonucunda oluşabilecek düşey deplasmanların sonlu elemanlar yöntemiyle belirlenmesi. Figure 10. Determination of vertical displacements after coal production by means of finite element model. 
Kıncal, Karakuş, Onur, Koca

belirlemiştir. Sübsidans ve fay etki zonları Şekil 3a ve Şekil 11'de gösterilmiştir.

Derinde (165 m kotunda) yeraltı kömür üretimi nedeniyle yüzeyde (elek yolunda ve yolun güneyinde yer alan eski harman sahasında) meydana gelen oturma şeklindeki deformasyonları kontrol eden tasman çatlakları, sübsidans profilini teşkil eden çökme ve çekme bölgelerinin oluşum mekanizmasına ve geometrisine uygun gelişmiştir (Şekil 12). Faya (K28D/90) bağlı olarak elek yolunun güneyinde yer alan şevler üzerinde atımları 0.3 $\mathrm{m}$ ile $1.0 \mathrm{~m}$ arasında değişen çok sayıda küçük fay gözlenmiştir. Faylar ve katmanlanmaya dik gelişmiş çatlakları aynı tektonik olaylar meydana getirmiştir. Tasman çatlaklarının konumlarının K25B ile K17D arasında değiştiği (K25B, K15B, K10B, K17D, K2B, K3B, K10D) belirlenmiştir. Gerek ana fayın (K28D/90) gerekse de küçük atımlı fayların konumları birbirleriyle yaklaşık örtüşmektedir (Şekil 13). Diğer bir anlatımla, söz konusu tasman çatlaklarının konumu K25B ile K17D arasında değişmektedir.

Fay zonu boyunca makaslamaya bağlı olarak çok kırıklı, kum cepleri içeren bir paralanma zonu (milonitik zon) gelişmiştir. Bu zon elek yolu boyunca yaklaşık $50 \mathrm{~m}$ uzunluğunda bir hattı kapsar (Şekil 3a). Beklenen durum; fayın etki zonunda (252 m), faya koşut önceden oluşmuş çatlaklar boyunca tasmanların gelişmesidir.

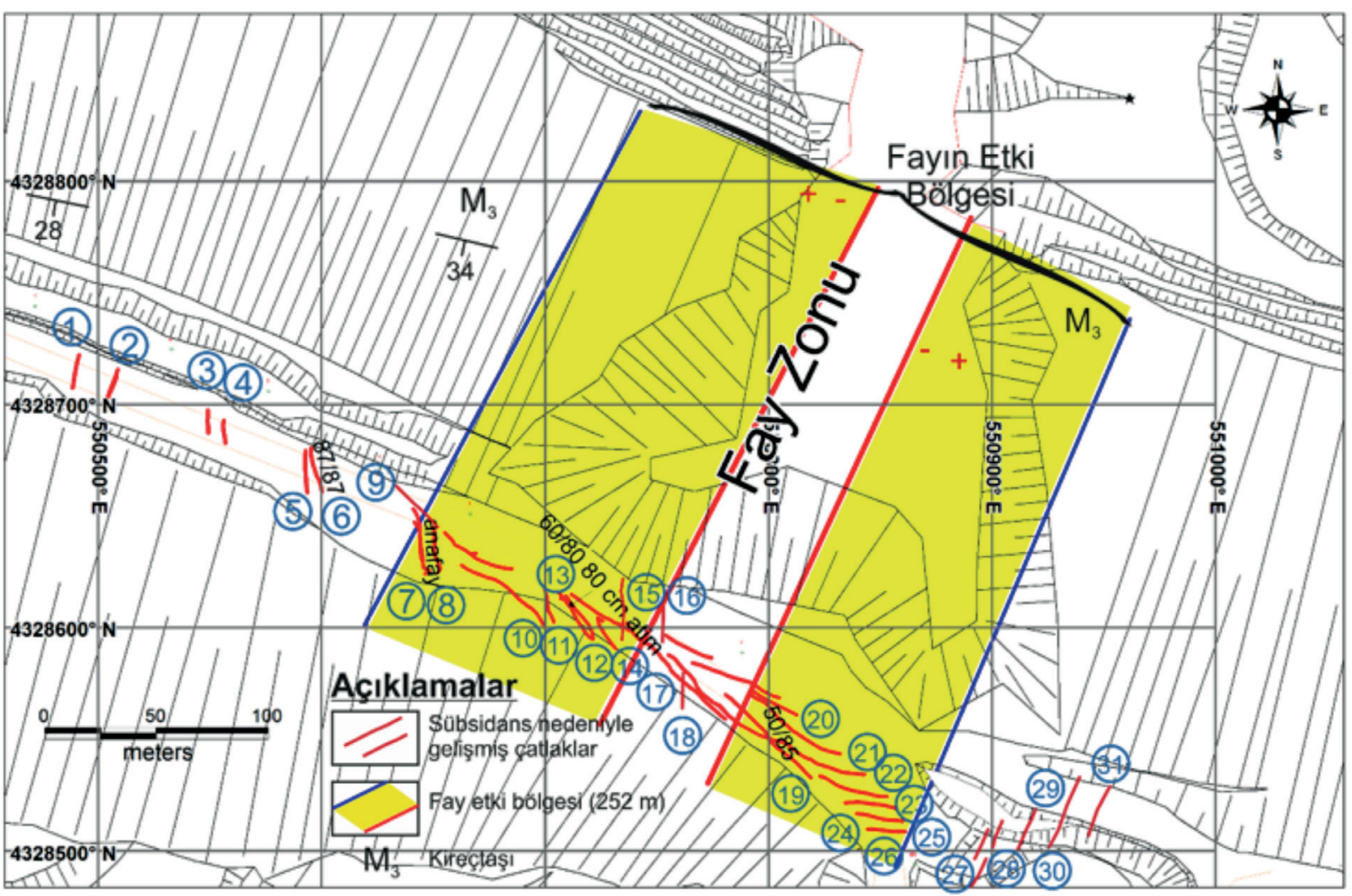

Şekil 11. Çökme nedeniyle elek yolu üzerinde gelişen tasman çatlaklarının haritası.

Figure 11. The map of subsidence crack pattern caused by subsidence developed on the run-off mine road. 


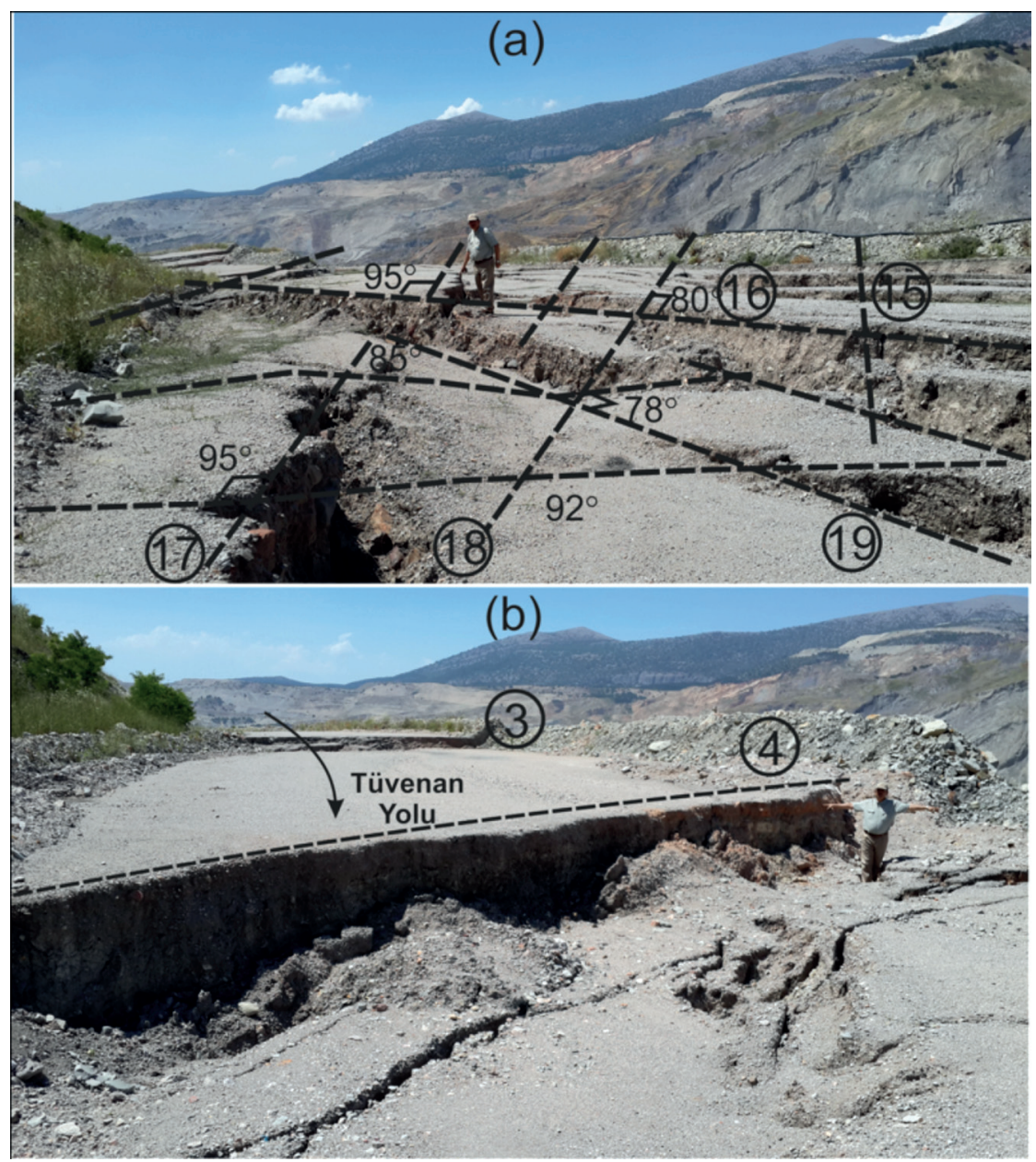

Şekil 12. (a) Fay zonu üzerinde birbirine yaklaşık dik gelişmiş tasman çatlakları (sübsidans çökme bölgesi), (b) Elek yolunu dikine kesen, sübsidans alanının çekme bölgesinde yer alan 3 ve 4 numaralı çatlaklar (fay etki sahasının dışında kalan bölge).

Figure 12. (a) Subsidence cracks developed nearly perpendicular to each other on the fault zone (subsidence zone), (b) 3 and 4-numbered cracks observed in the tensile zone of the subsidence which cut the run-off mine road perpendicularly.

Ölçüm ve gözlemler bunun tam tersi bir durumun geliştiğini göstermiştir (Şekil 11 ve 12a). Fay etki bölgesinde, fayın doğrultusuna dik tasman çatlakları gelişmiştir. Şekil $13 ; \mathrm{J}_{1}$ ve $\mathrm{J}_{2}$ çatlak takımlarının fayın doğrultusuna dik fakat ayakların uzun eksenlerine paralel bir şekilde geliştiğini göstermektedir. Fayın etki bölgesinde, faylanma nedeniyle $\mathrm{M}_{3}$-kireçtaşları sık çatlaklı kaya özelliğinde milonitik bir yapı kazanmıştır. Düşük kohezyon değerinde, kum zemin özelliği kazanmış malzemeler yer altı boşluğu nedeniyle, düşey yönde ve boşluğa doğru çökme etkisiyle fayın doğrultusuna dik yönde tasman çatlakları oluştururlar. Fayın etki bölgesinin dişında ise, fayın doğrultusuna paralel gelişmiş küçük atımlı faylar (fay tektoniğine bağlı oluşmuş) boyunca tasmanlar gelişmektedir (Şekil 11). Fayın etki alanının dışında gelişen tasman çatlaklarının doğrultusuyla fayın doğrultusu arasında ortalama $33^{\circ}$ açı farkının (en çok: $45^{\circ}$, en az: $8^{\circ}$ ) meydana 


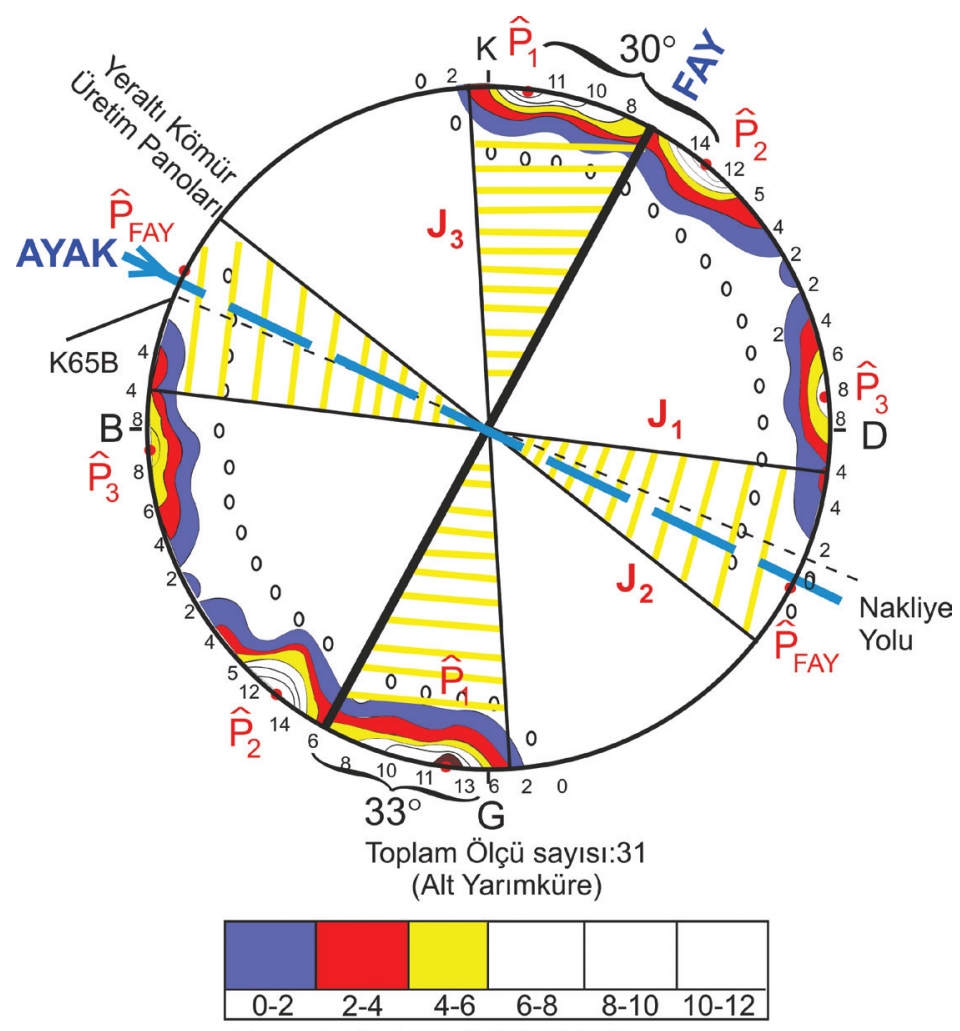

Fay: $118 / 90$ (K28D/90)

Şekil 13. Tasman çatlak konumlarından yararlanılarak hazırlanmış kontur diyagramı (kutup yoğunlaşma noktaları, elek yolu, ana fay zonu ve kömür üretim panellerinin konumları).

Figure 13. Contour diagram prepared by utilizing the subsidence cracks (pole concentration points, run-off mine road, fault zone, and the positions of the longwalls panels).

geldiği $\left(\mathrm{K} 5 \mathrm{~B}-\mathrm{K} 28 \mathrm{D}=33^{\circ}\right)$ saptanmıştır. Bu açı farkının nedeni; 165 m kotunda kömür üretimi nedeniyle oluşan yeraltı boşluğunun ve faylanma nedeniyle önceden (sübsidans meydana gelmeden önce) gelişmiş çatlakların varlığıdır. Elek yolunu dik kesen tasman çatlakları, iki faktörün bileşke kuvveti yönünde gelişmektedir. $\mathrm{Bu}$ yön de $\mathrm{J}_{3}$-çatlak takımına ait süreksizliklerin konumlandığ1 (K5B/90) yöndür. Milonitik özellikteki fay zonuna doğru çökme etkisiyle süreksizlik doğrultularında sapmalar meydana gelmektedir (Maksimum: 33º).

\section{KAZIK ÖLÇÜMLERİ}

Kömür üretimi nedeniyle oluşan yer altı boşlukları panoların üzerinde yer alan elek yolu üzerinde ilk tasman çatlaklarını Aralık 2013 tarihinde oluşturmuştur. Şekil 3a'da toplam 10 adet kazı ̆̆ın lokasyonları gösterilmiştir. 6 ve 7 numaralı lokasyonlar tam fay zonu üzerinde, 4 , 8 ve 9 numaralı lokasyonlar ise bu zonun her iki yanında kalan ve "fay etki bölgesi" olarak adlandırılan bölümlerde yer almaktadır (Şekil 14). 3, 4, 6, 7, 8 ve 9 numaralı lokasyonlarda tasman çatlaklarının konumları belirlenmiş ve 
analiz edilmiştir. Analiz sonucu olarak fay etki alanında yer alan kazıklarda günlük $3.8 \mathrm{~cm}$ 'ye varan deformasyonlar ölçülmüştür (Çizelge 1). İlk 125 günde 6 ve 7 numaralı kazıklarda sirasıyla $5.92 \mathrm{~m}$ ve $5.80 \mathrm{~m}$ en yüksek yer değiştirmeler ölçülmüştür. Daha sonraki 43 günde aynı kazıklarda sırasıyla $0.63 \mathrm{~m}$ ve 0.53 m yer değiştirmeler ölçülmüştür. 17.06.2014'ten 17.07.2014 tarihine kadar olan zaman diliminde bu miktarlar daha da azalarak $(<20 \mathrm{~cm}$.) devam etmiştir. Bunun nedeni; yeraltı üretim faaliyetinin, beklenmeyen süreçler nedeniyle (denetleme eksiklikleri, ocak yangını vb.) üretime ara vermiş olmasıdır. 10 nolu ölçüm noktası hariç (hareket yönü F5 fayına ve/veya kuzeybatıyadır), tüm ölçüm noktalarında hareket yönü düşey fayı göstermektedir (kuzeydoğuya doğru).

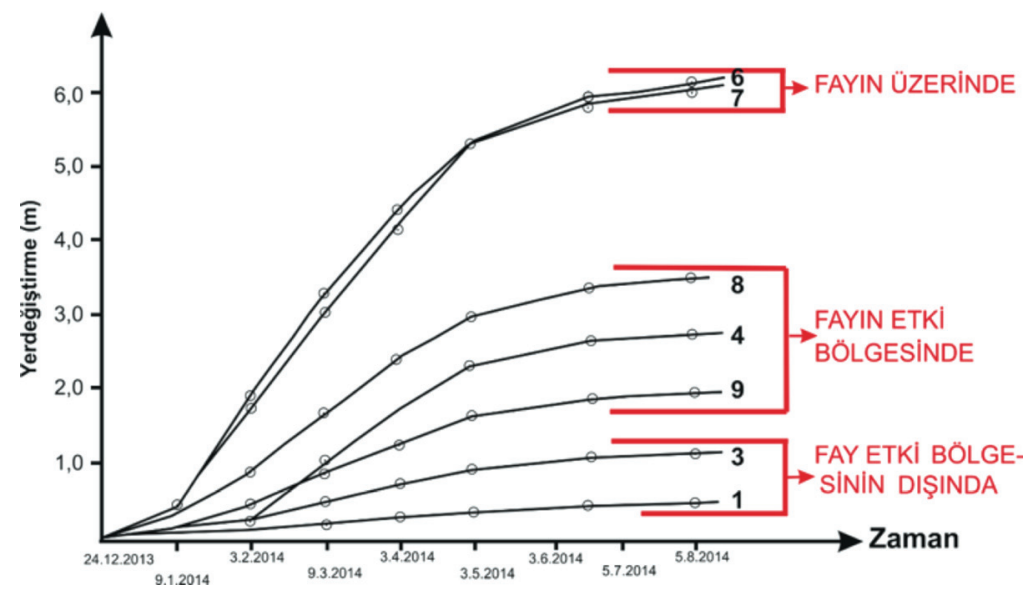

Şekil 14. Kazık ölçümleriyle bileşke yer değiştirme miktarları (m) arasındaki ilişkiler.

Figure 14. Relationship between survey measurements and quantities of the resultant displacements $(\mathrm{m})$.

Çizelge 1. Elek yolu üzerindeki kazıklarda farklı tarihlerde alınmış deformasyon ölçümleri.

Table 1. Deformation measurements recorded in different times at the survey monuments located on the run-off mine road.

\begin{tabular}{|c|c|c|c|c|c|c|c|c|c|c|}
\hline No & 24.12 .2013 & 03.01 .2014 & 03.02 .2014 & 03.03 .2014 & 03.04 .2014 & 05.05 .2014 & 17.06 .2014 & 3.7 .2014 \\
\hline & \multicolumn{7}{|c|}{ Kümülatif bileşke deformasyon $(\mathrm{m})$} \\
\hline 1 & 0 & 0.056789 & 0.109676 & 0.158470 & 0.239117 & 0.276465 & 0.323199 & - \\
\hline 2 & 0 & 0.052943 & 0.154081 & 0.337837 & 0.529360 & 0.648084 & 0.749871 & - \\
\hline 3 & 0 & 0.075723 & 0.207571 & 0.445486 & 0.694134 & 0.864532 & 1.010587 & - \\
\hline 4 & 0 & 0.124879 & 0.455189 & 1.075186 & 1.683110 & 2.254936 & 2.569196 & - \\
\hline 6 & 0 & 0.406153 & 1.734389 & 3.019739 & 4.159608 & 5.290198 & 5.917651 & $<20 \mathrm{~cm} *$ \\
\hline 7 & 0 & 0.379412 & 1.869351 & 3.259389 & 4.390497 & 5.276778 & 5.801797 & $<15 \mathrm{~cm} *$ \\
\hline 8 & 0 & 0.234970 & 0.878333 & 1.669789 & 2.370454 & 2.937248 & 3.298235 & - \\
\hline 9 & 0 & 0.139989 & 0.410336 & 0.880700 & 1.205531 & 1.576487 & 1.807265 & - \\
\hline 10 & 0 & 0,056329 & 0,078115 & 0,147597 & 0,140858 & 0,136638 & 0,196183 & - \\
\hline
\end{tabular}

Not: 5 numaralı lokasyon, sağlıklı ölçü alınamadığı için iptal edilmiştir.

* 17.06.2014 tarihi ile 3.7.2014 tarihi arasındaki ölçümlerde belirlenmiş olan kümülatif bileşke deformasyon miktarlarıdır. 


\section{FAY ETKİ BÖLGESIYLE ÜRETIM \\ PANOLARININ KONUMSAL İLIŞKISISININ DEĞERLENDİRILMESİ}

Ayaklar, yüzey çalışmaları sonucu belirlenen fay zonlarına dik açılmalıdır. Aksi durumda, fayın etki zonu genişlemekte ve bu durum da ayak boyunca daha uzun bir fay zonunun tahkim edilmesini gerekli kılmaktadır (Şekil 15). Kırıklı, paralanmış fay zonunun ayak boyunca etki mesafesinin artması zaman kaybına ve maliyet artışlarına neden olmaktadır. Kömür üretim panosu faya tam dik bir konumdaysa, fayın etki zonunun kalınlığı minimum değerde olmaktadır (Şekil 15). Doğrultular arasındaki açısal fark küçüldükçe fayın etki zonunun kesit boyunca kalınlığı artmaktadır. Bu durum kömür üretim maliyetini arttırmaktadır.

Ölçüm noktalarının düşey faya olan uzaklıkları ölçülen tasmanlarla ilişkilendirildiğinde; faya olan uzaklık azaldıkça tasman miktarlarının arttığı ortaya çıkmaktadır (Şekil 16). Bu ilişki araştırılırken sadece fay etki bölgesinde kalan ölçüm noktaları dikkate alınmıştır (3, 4, 6, 7, 8 ve 9 numaralı ölçüm noktaları). Elde edilen sonuçlara göre; yeraltı boşluğu nedeniyle oluşan tasmanların fay zonlarından doğrudan etkilendiği, hatta bu zonların tasmanları denetlediği sonucu ortaya çıkmaktadır.

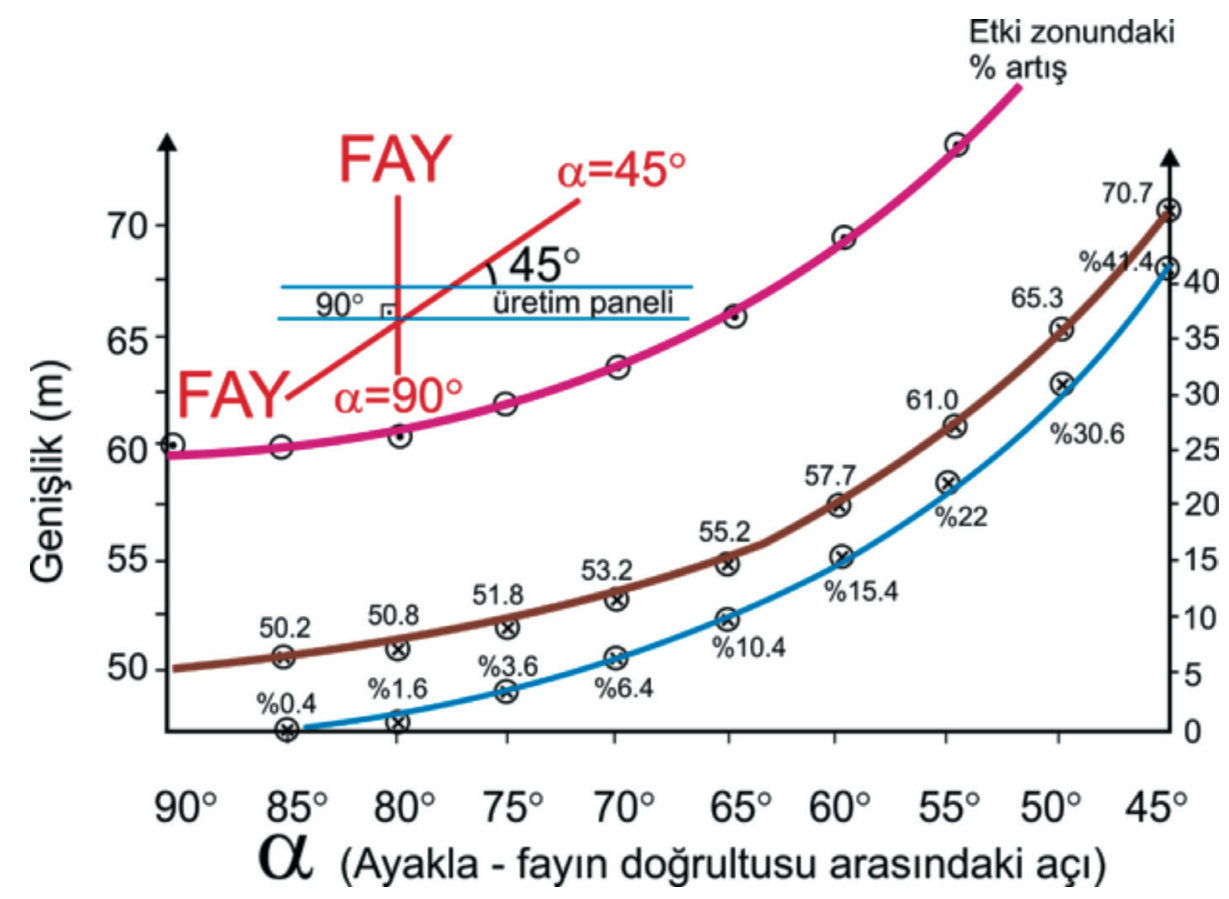

Şekil 15. $\alpha$-açısıyla (kömür üretim panoları ve fayın doğrultuları arasındaki açı) fayın etki zonunun genişliği arasındaki ilişkiler. Figure 15. Relationship between the width of fault influence zone and the $\alpha$-angle (angle between the strikes of fault and longwall panels). 


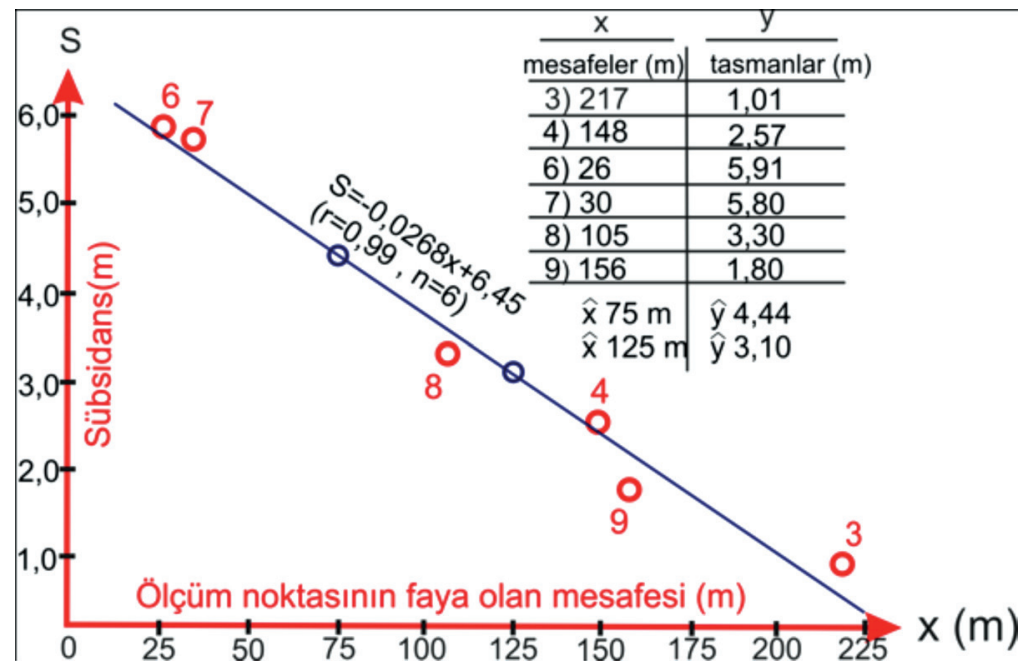

Şekil 16. Ölçüm noktalarının faya olan mesafeleriyle o noktalarda ölçülen tasman miktarları arasındaki ilişki.

Figure 16. Relationship between the distance of survery points to the fault zone and subsidence quantities.

\section{ÇATLAK DESENLERİ VE KAZIK ÖLÇÜMLERI YARDIMIYLA ELDE EDÍLEN SÜBSIDANS PROFÍİ}

Yüzeyde oluşan sübsidans elipsinin uzunluğu boyunca, diğer anlatımla elek yoluna koşut alınmış bir kesit (KB-GD yönlü) çıkartılmıştır (Şekil 17). Kömürün doğrultusuna yaklaşık paralel alınan kesitte tabakalar yaklaşık yataydır ( $\mathrm{a}=5^{\circ} \mathrm{GD}$ 'ya eğimlidir). Bu kesitte fay etkisi nedeniyle sübsidans profili değişmiş ve güneydoğu'ya doğru profil uzayarak asimetrik bir yapı kazanmıştır. Maksimum oturmalar fayın kendi üzerinde ölçülmüştür. Kesitte asimetrik yapı bu nedenle oluşmuştur. Elek yolu üzerinde gözlenen farklı çatlak desenleri ve kazıklardaki yer değiştirme miktarları dikkate alınarak, yola paralel kesitte sübsidans profili elde edilmiştir (Şekil 17). Kesitte çökme profili doğrudan kazık ölçüm sonuçları dikkate alınarak çizilmiştir. Sübsidans etki alanı ise hem $\mathrm{W}+1.4 \mathrm{~h}$ formülü kullanılarak hem de yüzey tasman çatlaklarının yer aldığ1 elek yolunun uzunluğu yerinde ölçülerek belirlenmiştir. Diğer taraftan, yolun kuzeybatısında kalan sübsidansa ait uzama bölgesinin geçtiği profil, doğrudan fay etki bölgesi dikkate alınarak çizilmiştir (Şekil 17).

Bilgisayar programiyla elde edilen sınır açıları profilin güneybatısı için $53^{\circ}$, kuzeydoğusu için $38^{\circ}$ olarak bulunmuştur (Şekil 10). Şekil $17^{\prime}$ deki kesitten ölçülen bu açılar ise; profilin kuzeybatısı için $63^{\circ}$, güneydoğusu için $45^{\circ}$ dir. Ortaya çıkan açısal farklar $7^{\circ}-10^{\circ}$ mertebesindedir. $\mathrm{Bu}$ farkın ortaya çıkmasının nedenleri şunlardır: a) çökmenin henüz tamamlanmamış olması, b) ayaklar ile elek yolunun tam olarak üst üste gelmemesi, c) ikisi arasında yatay mesafe farkının bulunması, d) $\mathrm{X}-\mathrm{X}^{\prime}$ kesitinin şevli topoğrafyaya sahip olması ve kömürü gerçek eğim değerinde kesmemesi, e) $Y-Y^{\prime}$ kesitinin fayın etkilerini barındırması, düz topoğrafyaya sahip olması ve de kömürü doğrultusu boyunca $\left(\mathrm{a}=5^{\circ}\right)$ kesmesidir. 


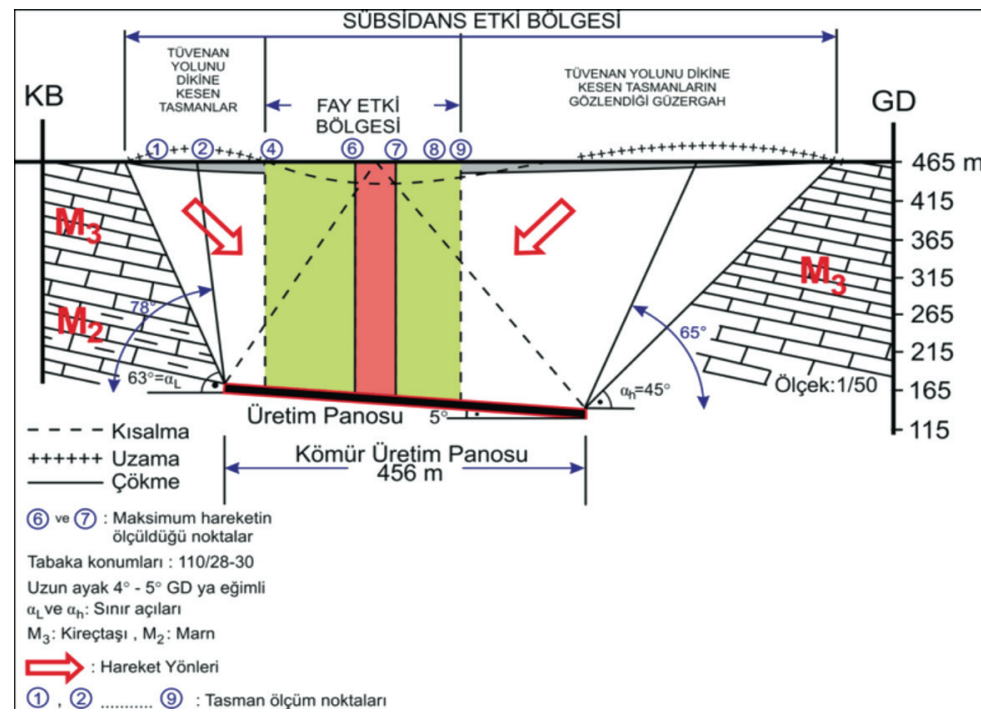

Şekil 17. Yüzeyde gözlenen çatlak desenleri ve tasman ölçüleri dikkate alınarak hazırlanan sübsidans profili.

Figure 17. Subsidence profile prepared considering the crack patterns observed on the surface and the subsidence measurements.

\section{SONUÇLAR}

Elek yolunu dik kesen düşey fay zonunun (K28D/90) ve bu yolun altında, yola paralel uzanmış ayaklardaki kömür üretimi nedeniyle gelişen yeraltı boşluklarından kaynaklanan tasmanların doğal olarak yüzeydeki çatlak desenlerinin oluşumunda ve gelişiminde etkili ve belirleyici olduğu sonucuna varılmıştır. Bununla birlikte elde edilen diğer sonuçlar şunlardır:

1. Tasman çatlakları fayın etki bölgesinde, fayın doğrultusuna hem dik hem de paralel yönde gelişmiştir. Paralel ve dik yönlerde olacak şekilde bu çatlaklar elek yolunu kesmiştir. Fayın etki bölgesi dışındaki alanlarda tasman çatlakları fayın doğrultusuna yaklaşık paralel (açı fark1 min: $8^{\circ}$, maks: $33^{\circ}$ ) konumda, elek yoluna dik geliştiği belirlenmiştir. Buna göre fayın yola dik ve/veya yaklaşık dik olduğu konumlarda, tasman çatlaklarının oluşturduğu desenlere bakarak çökme ve çekme bölgelerinin lokasyonları doğru bir şekilde yüzeyden belirlenebilir.Böylelikle, fay zonunun kuzeybatısında 110 metrelik, güneydoğusunda 78 metrelik zonların fayın etki alanında kaldığ 1 belirlenmiştir. Fayın kendi zonuyla birlikte "fay etki bölgesi" elek yolu boyunca $252 \mathrm{~m}$ bir yol güzergâhını kapsamaktadır. Asimetrik tasman profilinin gelişmesinin ana nedeni fayın varlığıdır. Tâli neden ise kömür üretim panolarının kesit boyunca $5^{\circ}$ güneydoğuya eğimli olarak açılmasıdır.

2. Yedi aylık zaman içerisinde 10 farklı noktada belli aralıklarla ölçülen tasmanların toplam değerleri hesaplanmıştır. Maksimum düşey yer değiştirmeler 6 ve 7 numaralı ölçüm noktalarında sırasıyla $5.92 \mathrm{~m}$ ve 5.80 m olarak ölçülmüştür. Bu iki ölçüm noktası tam düşey fayın üzerinde yer almaktadır. Fayın her iki yanında yer alan fay etki bölgelerinde ve bu bölgelerin dışında da ölçümler yapılmıştır. En düşük deplasmanlar 
fay etki bölgesi dışında yer alan noktalarda $£$ 1.0 m olarak ölçülmüştür. Uzun ayaklar elek yolunun altında ve $291 \mathrm{~m}$ derinlikte, tüm ölçüm noktalarına yaklaşık eşit mesafededir. $\mathrm{Bu}$ durum fay etkisinin yüzeyde gelişen çatlak deseninin oluşmasında en belirleyici parametre olduğunu ortaya koymaktadır.

3. Bilgisayar programı kullanılarak yapılan analizlerde, toplam $7.5 \mathrm{~m}$ 'ye varan düşey yer değiştirmelerin meydana geleceğ $i$ hesaplanmıştır. Meydana gelen tasmanların maksimum 5.92 m olduğu (6 nolu ölçüm noktası) göz önüne alındığında; toplam tasmanların ancak \%80'inin tamamlandığ 1 anlaşılmaktadır. $\mathrm{Bu}$ nedenle, sonraki dönemlerde de hareketin bir süre daha devam edeceği öngörülmektedir.

4. Elek yoluna dik ve paralel kesitlerde kırılma açıları farklı yöntemler kullanılarak elde edilmiştir. Dik kesitte kırılma açıları profilin güneybatısı için $53^{\circ}$, kuzeydoğusu için $38^{\circ}$ olarak belirlenirken, paralel kesitte bu açılar $63^{\circ}$ ve $45^{\circ}$ olarak ölçülmüsstür. Bu fark, iki kesitin topografyasının farklı olmasından, faya paralel ve dik kesitler olmalarının yanı sıra kömürü gerçek eğim değerinde kesip kesmemeleriyle ilgilidir.

\section{KATKI BELİRTME}

Yazarlar, Işıklar panosunda (Soma/ Manisa) yapılan arazi çalışmaları ile ilgili olarak yardım ve desteklerinden dolayı T.K.İ. E.L.İ. İşletme Müdürü Hakkı Duran'a, İşletme Müdür Yardımcısı İsmail Ceran'a, Soma İstihsal İşletme Müdürü N. Coşkun Ok'a, Maden Mühendisi Ekrem Demir'e ve Harita Mühendisi Gürhan Karapınar'a teşekkür eder.

\section{KAYNAKLAR}

Aksoy, C. O., Köse, H., Onargan, T., Koca, M.Y., Heasley, K., 2004. Estimation of limit angle using laminated displacement discontinuity analysis in the Soma coal field, Western Turkey. International Journal of Rock Mechanics and Mining Sciences, 41, 547-556.

Goodman, R. E., 1976. Methods of Geological Engineering in Discontinuous Rocks. West Publishing Company, St. Paul, MN, 170-207.

Kıncal, C., Koca, M. Y., 2009. A proposed method for drawing the great circle representing dip angle and strike changes. The Geological Society of America (AEG), Vol. XV, No.2, 145-165.

Koca, M. Y., Kıncal, C., 2004. Abandoned stone quarries in and around the Izmir city centre and their geo-environmental impacts-Turkey. Engineering Geology, 75 (1), 49-67.

National Coal Board (NCB), 1975. Subsidence Engineer's Handbook. National Coal Board, London, $111 \mathrm{p}$.

Onargan, T., Koca, M. Y., Köse, H., 2000. Determination of "Break Angle" from subsidence cracks in Soma-Eynez coal field of Turkey. $7^{\text {th }}$ National Mine Surveying Conference with International Participation, 189-201.

Oncioiu, G., Onica, I., 1999. Ground deformation in the case of underground mining of thick and dip coal seams in the Jiu Valley Basin. $18^{\text {th }}$ Conference on Ground Control in Mining West Virginia, 334 p.

Phase $^{2} . v .7,2014$. Phase ${ }^{2}$ software, https://www. rocscience.com/products/3/updates/1

Singh, K. B., Dhar, B. B., 1997. Sinkhole subsidence due to mining. Geotechnical and Geological Engineering, 15, 327-341.

Whittaker, B. N., Reddish, D. J., 1989. Subsidence Occurrence, Prediction and Control. Elsevier, $528 \mathrm{p}$. 
